\title{
PERANCANGAN TANGAN PROSTHESIS BAWAH SIKU BERBASIS FLEXY HAND 2 DAN FLEX SENSOR
}

\author{
Firdhaus Hari Saputro Al Haris ${ }^{1)}$, Rahmat Wisudawanto ${ }^{2)}$ Alpin Kurnia Putra ${ }^{3)}$ \\ ${ }^{1,2,3}$ Program Studi Informatika, Universitas Sahid Surakarta \\ 1,2,3 Jl. Adi Sucipto no. 154 Jajar, Surakarta \\ Email: ${ }^{1}$ edoz2003@gmail.com, ${ }^{2}$ wisudawanto@gmail.com, ${ }^{3}$ alpheen.putra@gmail.com
}

\begin{abstract}
One of the best ways to rehabilitate persons with disabilities is to use prostheses. However, not all persons with disabilities, especially those with disabilities on the hands can use all types of prosthesis hands. The purpose of this research is to develop Flexy Hand 2 into a $3 D$ Printing-based prosthesis hand that is wider in its scope of use. The method used in this research is trial and error. The scope of the user of this prosthesis hand is a person with disabilities below the elbow who still has one other hand that still has at least 3 fingers. The result of this research is a prosthetic hand that can move the entire finger and can mimic it basic hand movements such as grasping objects and picking up objects with a delay between the transmitter and receiver modules ranging from 132 milliseconds to 260 milliseconds. The entire modules works at a voltage of $5 \mathrm{~V}$ which means the hand can be turned using a portable power supply.
\end{abstract}

Keyword: Disabilities, Prosthetic Hand, Flexy Hand 2, Flex Sensor, Trial and Error.

\begin{abstract}
Abstrak
Salah satu cara untuk merehabilitasi penyandang tuna daksa adalah dengan menggunakan prosthesis. Tetapi, tidak semua penyandang tuna daksa, khususnya penyandang tuna daksa bagian tangan dapat menggunakan segala jenis tangan prosthesis. Tujuan dari penelitian ini adalah mengembangkan Flexy Hand 2 menjadi tangan prosthesis berbasis $3 D$ Printing yang lebih luas dalam ruang lingkup penggunaannya. Metode yang di dalam penelitian ini menggunakan metode trial and error. Cakupan pengguna dari tangan prosthesis ini adalah penyandang tuna daksa bagian bawah siku yang masih memiliki satu tangan lain yang masih memiliki jari minimal 3 buah. Hasil dari penelitian ini adalah tangan prosthesis yang dapat digerakkan keseluruhan jarinya dan dapat menirukan gerakan dasar tangan seperti menggenggam benda dan mengambil benda dengan delay antara modul transmitter dan receiver berkisar 132 milisecond hingga 260 milisecond. Keseluruhan modul bekerja pada tegangan $5 \mathrm{~V}$ yang berarti tangan dapat dihidupkan menggunakan catu daya portable.
\end{abstract}

Kata Kunci: Tuna daksa, Tangan Prosthesis, Flexy Hand 2, Flex Sensor, Trial and Error.

\section{Pendahuluan}

Penyandang Disabilitas adalah orang yang mengalami keterbatasan fisik, intelektual, mental, dan/atau sensorik dalam jangka waktu lama yang dalam berinteraksi dengan lingkungan dapat mengalami hambatan dan kesulitan untuk berpartisipasi secara penuh dan efektif dengan warga negara lainnya berdasarkan kesamaan hak [1]. Sedangkan yang dimaksud keterbatasan fisik, diantaranya tuna netra (hambatan penglihatan), tuna rungu (hambatan pendengaran dan bicara), tuna daksa (cacat tubuh, seperti mengalami polio dan gangguan gerak) [2]. Data Riskesdas menunjukkan bahwa $0,08 \%$ anak usia 24-59 bulan merupakan menyandang tunadaksa, baik karena penyakit, ataupun trauma/kecelakaan [3]. Dalam data Susenas 2013 disebutkan bahwa persentase penduduk disabilitas di Indonesia sebesar 2.45\% [4]. Besaran penduduk disabilitas di Indonesia diperparah dengan banyaknya penderita penyakit diabetes melitus yang menjadi penyebab terjadinya amputasi dan disabilitas lainnya [5].

Salah satu cara untuk merehabilitasi penyandang tuna daksa adalah dengan menggunakan alat bantu gerak atau prosthesis. Prosthesis adalah perangkat artifisial untuk menggantikan bagian tubuh yang hilang, baik karena trauma, penyakit, maupun cacat kongenital [6]. Salah satu jenis prosthesis adalah body-powered prosthesis, yaitu prosthesis yang digerakkan dengan sistem kabel yang memungkinkan penggunanya untuk memegang benda, melenturkan ataupun mengunci siku [7]. Kelemahan dari prosthesis jenis body-powered adalah kenyamanan penguna yang terabaikan karena kabel-kabel yang diikatkan pada bagian tubuhnya.

Pada tahun 2012, e-Nable [8], yang merupakan komunitas non-profit menciptakan $3 D$ model pertama tangan prosthesis body-powered untuk anak-anak. $3 D$ model tersebut dapat dicetak menggunakan $3 D$ printer, yaitu sebuah alat fabrikasi komputer dekstop atau 
manufaktur aditif yang digunakan untuk proses prototyping dimana membuat benda nyata dari model 3D [9]. Terutama pada kasus tunadaksa bawah siku, tangan prosthesis yang dibuat dengan $3 D$ Printer tergolong lebih mudah digunakan dibandingkan tangan prosthesis konvensional.

Pada tahun 2016, komunitas e-Nable [10] merilis Flexy Hand by Gyrobot yang lebih mirip dengan bentuk tangan manusia. Flexy Hand by Gyrobot, dikhususkan untuk tuna daksa yang tidak memiliki jari tangan, tetapi masih memiliki bagian telapak tangan (carpals dan metacarpals). Ilustrasi penggunaan Flexy Hand by Gyrobot ditunjukkan pada Gambar 1.

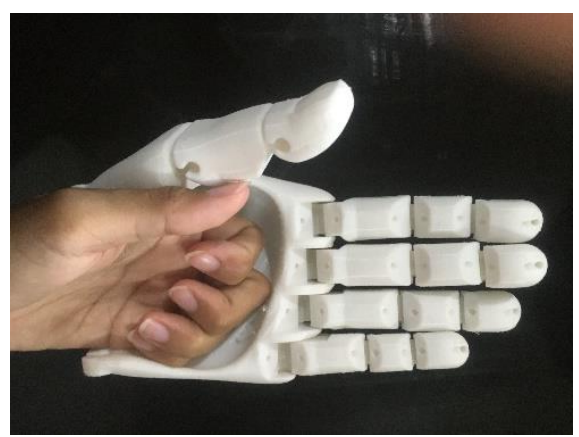

Gambar 1. Ilustrasi Penggunaan Flexy Hand Bagi Tuna Daksa

Perancangan tangan prosthesis bawah siku berbasis Flexy Hand 2 dan flex sensor bertujuan untuk mengembangkan Flexy Hand 2 by Gyrobot yang tergolong sebagai body-powered prosthesis menjadi tangan prosthesis bertenaga listrik. Selain itu, tangan prosthesis yang dikembangkan memiliki cakupan penggunaan yang lebih luas, yaitu dapat digunakan oleh penyandang tuna daksa bawah siku. Selanjutnya, tangan prosthesis ini juga dirancang untuk mengembangkan tangan prosthesis jenis electromyogram (EMG) yang digerakkan dengan sinyal myoelectric, yang diperoleh dari pembacaan sensor yang ditempelkan pada seraput serat otot tangan [11]. Kelemahan tangan prosthesis jenis EMG adalah membutuhkan banyak penyesuaian dan mungkin tidak dapat digunakan oleh semua tuna daksa [7].

Tangan prosthesis bawah siku yang dirancang dibuat dengan sensor utama yaitu flex sensor. Flex sensor atau dikenal juga dengan bending sensor merupakan sensor yang mendeteksi tingkat kelengkungan yang diperoleh dengan cara menempelkan sensor pada objek yang dilengkungkan [12]. Nilai yang diperoleh oleh flex sensor merupakan nilai $A D C$ (Analog to Digital Converter). Nilai konversi $A D C$ kemudian diproses didalam modul transmitter, kemudian ditransmisikan melalui media $\mathrm{WiFi}$ ke modul receiver menggunakan modul nRF24L01, yaitu nRF24L01 merupakan modul komunikasi transceiver jarak jauh yang menggunakan frekuensi pita gelombang radio 2.4-2.5 GHz ISM (Industrial Scientific and Medical) [13].

\section{Metode}

Penelitian ini menggunakan metode trial and error.
Gambaran lengkap alur penelitian ditunjukkan pada Gambar 2.

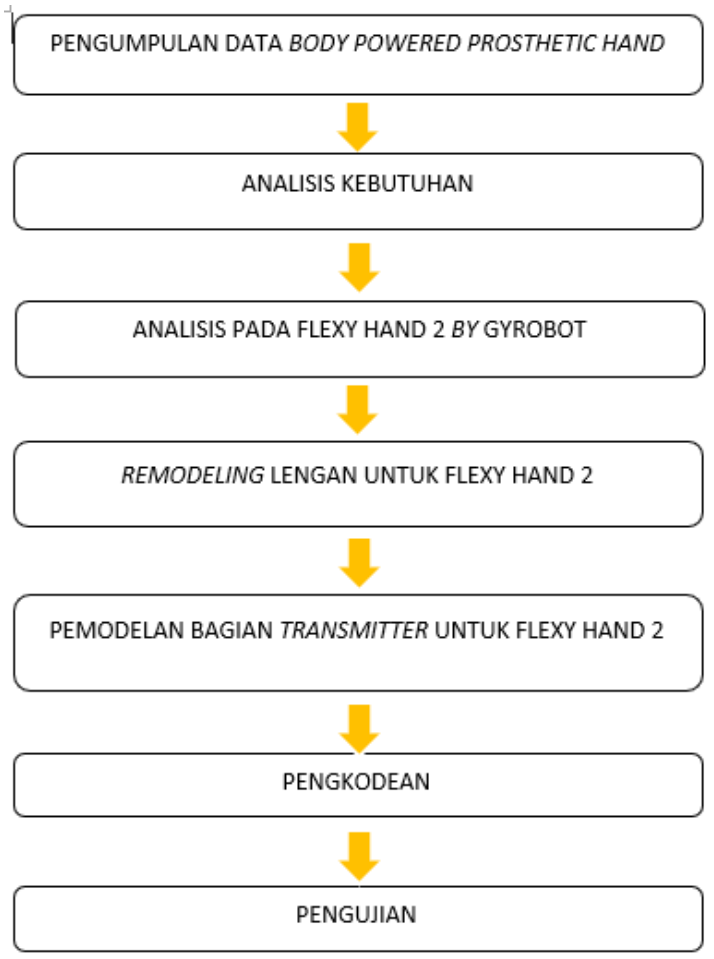

Gambar 2. Alur Penelitian

\section{Pengumpulan Data Body Powered Prosthetic Hand}

Tahapan ini digunakan untuk mengumpulkan data terkait body powered prosthetic hand. Data yang dikumpulkan berupa berbagai jenis body powered prosthetic hand yang saat ini telah dibuat, baik berupa prototipe maupun produk untuk mass production. Data yang terkumpul tersebut akan dijadikan baseline untuk menjalankan penelitian.

\section{Analisis Kebutuhan}

Tahapan analisis kebutuhan digunakan untuk menggambarkan kondisi objek penelitian, alat dan bahan yang digunakan dalam penelitian, serta block diagram dari produk hasil penelitian.

\section{Analisis Pada Flexy Hand 2 by Gyrobot}

Tahapan ini digunakan untuk mengobservasi secara langsung pada produk Flexy Hand 2 by Gyrobot yang menjadi base model dalam penelitian ini. Tahapan ini menghasilkan output berupa informasi terkait dengan kelemahan yang ditemukan pada Flexy Hand 2 by Gyrobot apabila diimplementasikan sebagai base model dalam penelitian ini.

\section{Remodeling Lengan untuk Flexy Hand 2}

Tahapan ini membutuhkan output dari analisis pada Flexy Hand 2 by Gyrobot. Pada tahapan ini, kelemahan pada model tangan Flexy Hand 2 by Gyrobot, khususnya 
pada bagian lengan akan di model ulang dengan menggunakan aplikasi $C A D$.

\section{Pemodelan Bagian Transmitter Untuk Flexy Hand 2}

Tahapan ini merupakan pemodelan pada bagian transmitter, yaitu modul untuk menangkap gerakan tangan yang masih sehat.

\section{Pengkodean}

Bagian ini merupakan bagian untuk membuat baris kode untuk menjalankan sistem tangan prosthesis berbasis Flexy Hand 2.0 dan Flex Sensor.

\section{Pengujian}

Pada tahapan ini akan dilakukan tiga jenis pengujian, yaitu pengujian sensor, pengujian delay, dan pengujian fungsional dari hasil penelitian perancangan tangan prosthesis bawah siku berbasis Flexy Hand 2 dan flex sensor ini. Pengujian sensor menggunakan program Serial Monitor Arduino. Pengujian delay akan menggunakan Serial Monitor Arduino berdasarkan standar TIPHON kategori delay [14]. Tabel klasifikasi delay menurut TIPHON dijabarkan pada Tabel 1.

Tabel 1. Kategori Delay

\begin{tabular}{ccc}
\hline Kategori Delay & $\begin{array}{c}\text { Besar Delay } \\
\text { (dalam millisecond) }\end{array}$ & Indeks \\
\hline Sangat Bagus & $<150$ & 4 \\
Bagus & 150 s.d 300 & 3 \\
Sedang & 300 s.d 450 & 2 \\
Buruk & $>450$ & 1 \\
\hline
\end{tabular}

Pada pengujian fungsional akan dilakukan secara kualitatif, yaitu dengan mengamati hasil pengujian secara langsung.

\section{Hasil dan Analisis}

\section{Analisis Kebutuhan}

Perancangan tangan prosthesis bawah siku berbasis Flexy Hand 2 dan flex sensor ini dikhususkan untuk tuna daksa bagian bawah siku (transradial) dan mengharuskan pasien memiliki satu tangan lain dengan minimal 3 jari tangan yang masih sehat.

Cara kerja tangan prosthesis ini adalah dengan menangkap pergerakan jari tangan pasien yang masih sehat yang diolah melalui flex sensor lalu kemudian ditransmisikan ke modul receiver yang kemudian akan dikonversi menjadi nilai rotasi motor servo yang akan menggerakkan jari-jari pada tangan prosthesis. Diagram alir cara kerja tangan prosthesis ditunjukkan pada Gambar 3.

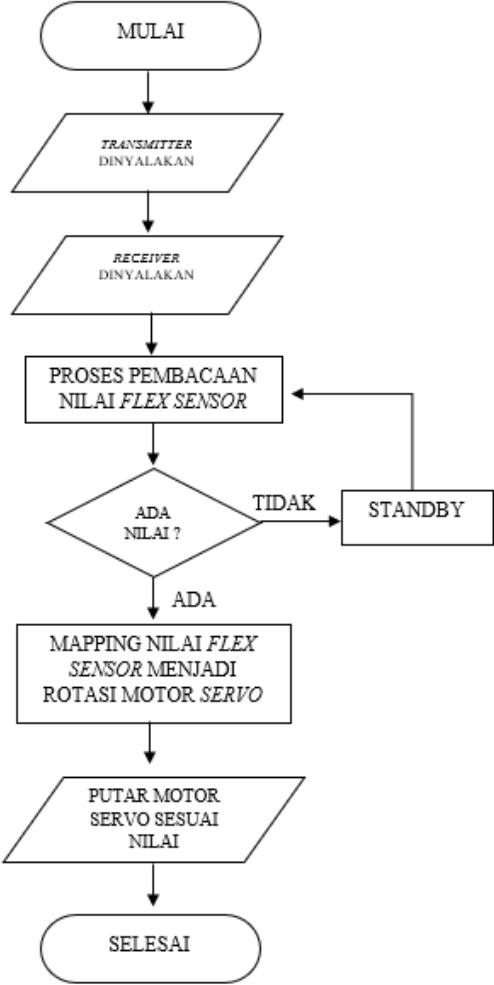

Gambar 3. Diagram Alir Cara Kerja Tangan Prosthesis

Sedangkan block diagram dari perancangan tangan prosthesis bawah siku berbasis Flexy Hand 2 dan Flex Sensor ini ditunjukkan pada Gambar 4.

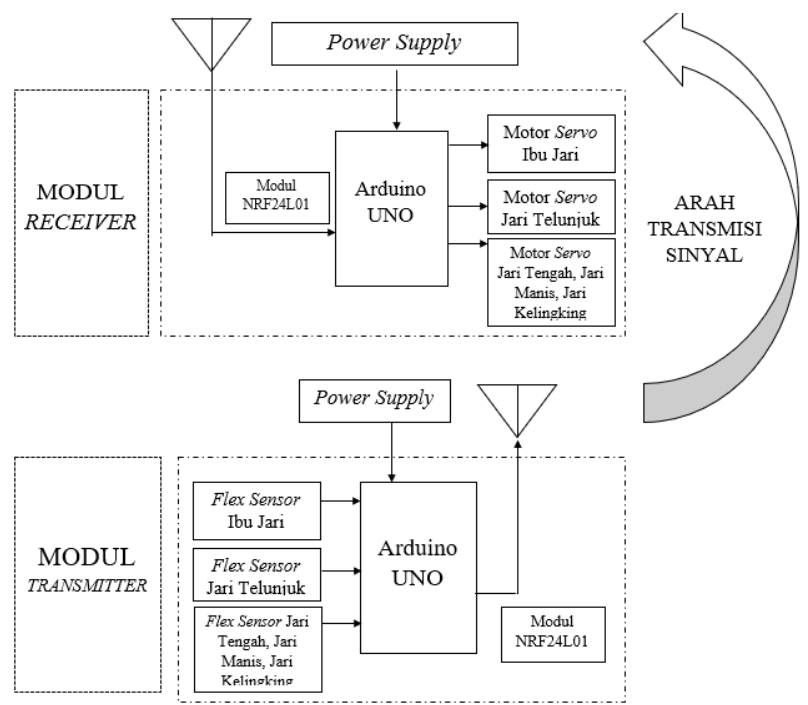

Gambar 4. Block Diagram Tangan Prosthesis

Berdasarkan block diagram pada Gambar 4 dijelaskan bahwa flex sensor dipasang pada ibu jari, jari telunjuk, dan jari tengah. Kemudian, nilai pembacaan akan diolah pada mikrokontroler dan dikonversi menjadi nilai $A D C$ lalu dikonversi lagi menjadi nilai rotasi pada motor servo. Hasil yang telah dikonversi, kemudian dikirim pada modul receiver melalui modul WiFi NRF24L01, kemudian oleh modul receiver, nilai tersebut akan digunakan untuk memutar motor servo pada tangan prosthesis. 
Pemasangan flex sensor pada tiga jari tersebut didasari oleh sistem capit pada tangan prosthesis konvensional yang digunakan pada tiga jari tersebut. Pada tangan prosthesis konvensional, rangka capit tersebut akan dimasukkan kedalam sarung yang berbentuk tangan. Rangka capit tersebut dipasangkan ke ibu jari, jari telunjuk, dan jari tengah. Sedangkan pada jari manis dan jari kelingking, biasanya akan diisi dengan campuran bahan gypsum.

\section{Analisis Pada Flexy Hand 2 by Gyrobot}

Flexy Hand 2 by Gyrobot merupakan salah satu jenis tangan prosthesis body-powered yang dibuat dengan $3 D$ Printer. Flexy Hand 2 by Gyrobot dijadikan sebagai base model pada penelitian ini dengan pertimbangan kemiripan bentuk dan estetika model yang menyerupai tangan asli. Hasil pencetakan 3D dari Flexy Hand 2 by Gyrobot ditunjukkan pada Gambar 5.

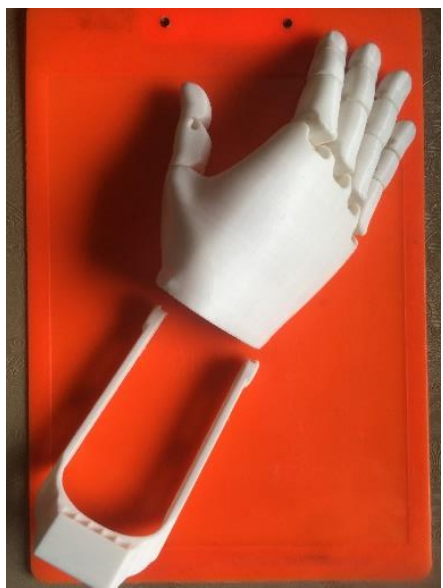

Gambar 5. Hasil Pencetakan Flexy Hand 2 by Gyrobot

Pencetakan 3D dari Flexy Hand 2 by Gyrobot menggunakan bahan Polyactic acid (PLA) dengan pengaturan printer yang dijabarkan pada Tabel 2.

Tabel 2. Pengaturan $3 D$ Printer

\begin{tabular}{cll}
\hline No. & Komponen & Pengaturan \\
\hline 1 & Nozzle Temperature & $200^{\circ} \mathrm{C}$ \\
2 & Bed Temperature & $60^{\circ} \mathrm{C}$ \\
3 & Nozzle Diameter & $0.4 \mathrm{~mm}$ \\
4 & Layer Height & $0.2 \mathrm{~mm}$ \\
5 & Printing Support & Enabled \\
\hline
\end{tabular}

Dari hasil analisis yang didapatkan, diperlukan pemodelan ulang pada bagian lengan untuk meletakkan motor servo dan modul tangan prosthesis. Selain itu, pada bagian pergelangan tangan akan dibuat statis untuk memperoleh torsi maksimal dari motor servo.

\section{Remodeling Lengan untuk Flexy Hand 2 by Gyrobot}

Berdasarkan analisis yang telah dilakukan pada Flexy Hand 2 by Gyrobot maka dilakukan remodeling lengan dengan menggunakan aplikasi Fusion 360. Hasil remodeling ditunjukkan pada Gambar 6 .

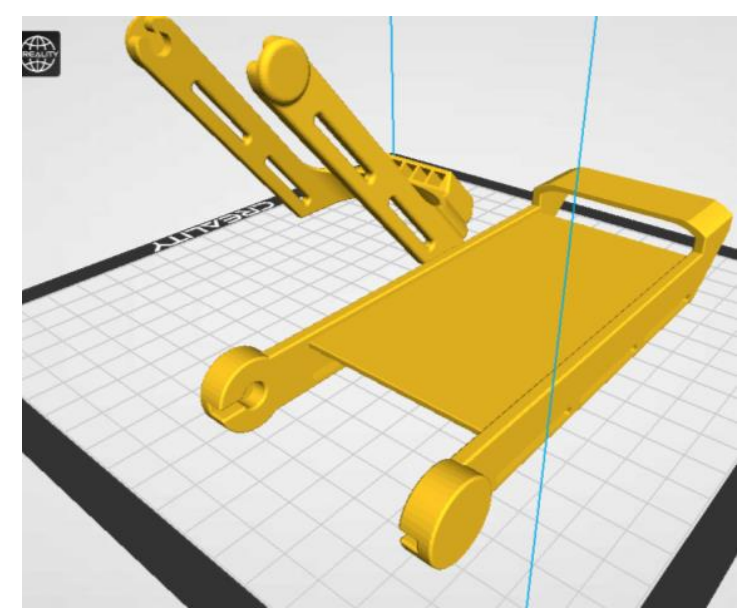

Gambar 6. Lengan Existing Pada Flexy Hand (belakang) dan Lengan Hasil Remodeling (Depan)

Berdasarkan Gambar 6, ditunjukkan bahwa telah dilakukan perubahan pada bagian lengan dengan menambah base sebagai tempat untuk meletakkan motor servo dan modul mikrokontroler untuk receiver. Adapun komponen yang terpasang sebagai modul receiver ditunjukkan pada Tabel 3.

Tabel 3. Komponen yang Terpasang Pada Modul Receiver

\begin{tabular}{cll}
\hline No. & Komponen & Fungsi \\
\hline 1 & Arduino UNO & Modul mikrokontroler \\
2 & 5V Power Supply & Sumber tegangan \\
3 & NRF24L01 Shield & $\begin{array}{l}\text { Modul voltage divider } \\
\text { untuk NRF24L01 }\end{array}$ \\
& & Modul WiFi \\
4 & NRF24L01 Modules & Penggerak jari tangan \\
5 & 3 x Motor Servo & Penghubung antara \\
6 & Tali Nylon & motor servo dan jari \\
& & tangan \\
& & Stabilizer untuk sumber \\
7 & Kapasitor $4700 \mu \mathrm{F}$ & tegangan motor servo \\
& 16V &
\end{tabular}

Skema pemasangan modul receiver ditunjukkan pada Gambar 7.

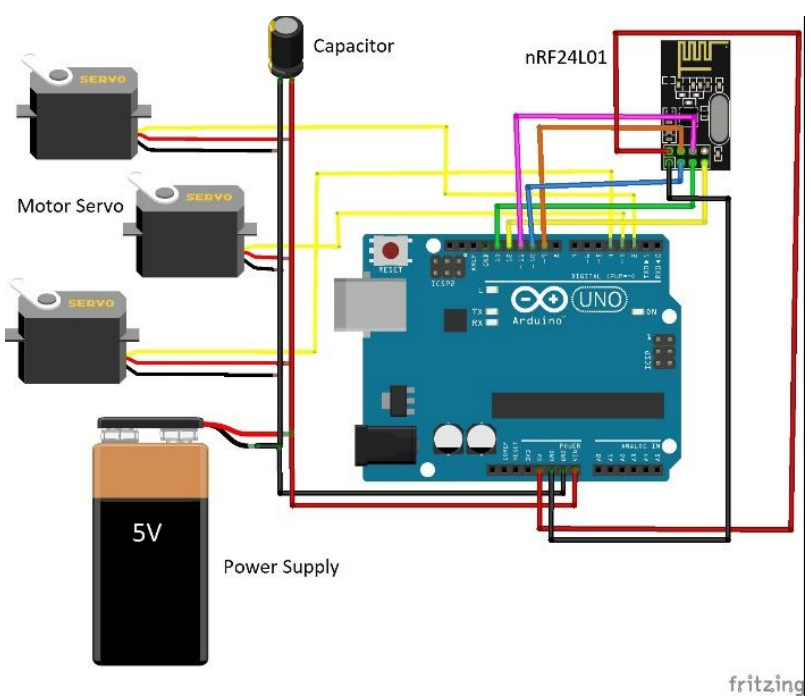

Gambar 7. Skema Pemasangan Modul Receiver 


\section{Pemodelan Bagian Transmitter untuk Flexy Hand}

Bagian transmitter merupakan bagian untuk menangkap gerakan tangan yang masih utuh dengan menggunakan flex sensor. Bagian transmitter akan diberi casing dengan $3 D$ Model yang ditunjukkan pada Gambar 8.

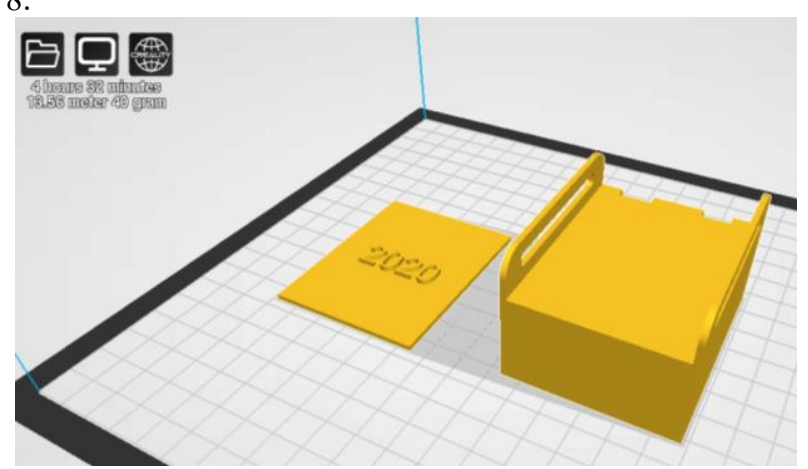

Gambar 8. Casing Modul Transmitter

Komponen yang terpasang pada bagian transmitter ditunjukkan pada Tabel 4.

Tabel 4. Komponen yang Terpasang Pada Modul Transmitter

\begin{tabular}{|c|c|c|}
\hline No. & Komponen & Fungsi \\
\hline 1 & Arduino UNO & Modul mikrokontroler \\
\hline 2 & 5V Power Supply & Sumber tegangan \\
\hline 3 & NRF24L01 Shield & $\begin{array}{l}\text { Modul voltage divider } \\
\text { untuk NRF24L01 }\end{array}$ \\
\hline 4 & NRF24L01 Modules & Modul WiFi \\
\hline 5 & $3 \times$ Flex Sensor & $\begin{array}{l}\text { Mengubah pergerakan } \\
\text { jari tangan menjadi nilai } \\
\text { analog }\end{array}$ \\
\hline
\end{tabular}

Skema pemasangan modul transmitter ditunjukkan pada Gambar 9.

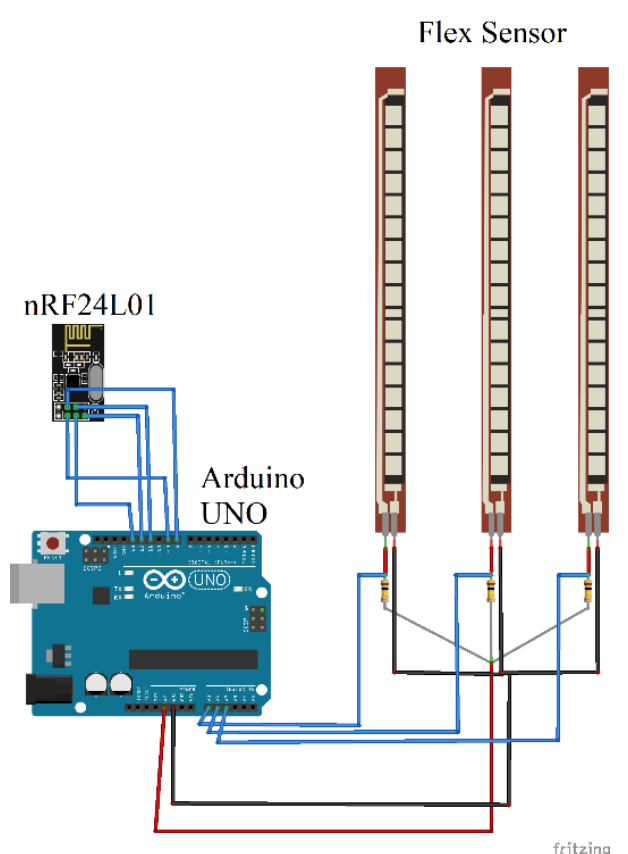

Gambar 9. Skema Pemasangan Modul Transmitter

\section{Pengkodean}

Setelah pemodelan dan skema pemasangan modul selesai dibuat dan dirakit, langkah berikutnya adalah pengkodean. Pengkodean dilakukan dengan menggunakan Arduino IDE dalam bahasa pemrograman $\mathrm{C}++$. Bagian kode yang digunakan untuk mengolah pergerakan jari tangan menjadi nilai rotasi motor servo ditunjukkan pada Gambar 9.

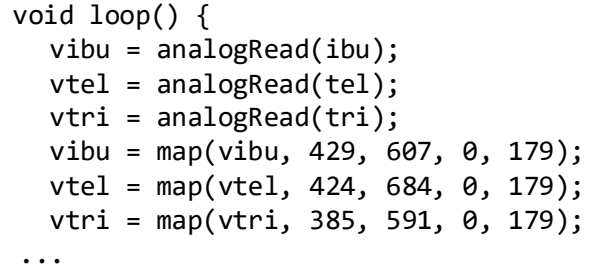

Gambar 9. Kode Program Untuk Konversi Nilai ADC ke dalam Range Nilai Rotasi Motor Servo

Pada Gambar 9 ditunjukkan fungsi map(), yaitu fungsi untuk mengkonversi range nilai ADC (Analog to Digital Converter) ke dalam range nilai rotasi motor servo.

\section{Pengujian}

Pada tahapan pengujian dilakukan tiga jenis pengujian, yaitu pengujian sensor, pengujian delay, dan pengujian fungsional. Pengujian sensor adalah pengujian yang berkaitan dengan flex sensor dan nilai ADC yang didapatkan. Pengujian delay berkaitan dengan lamanya delay untuk mengirimkan nilai dari transmitter ke bagian receiver. Sedangkan, pengujian fungsional merupakan pengujian keseluruhan dari tangan prosthesis yang dibuat.

\section{Pengujian Sensor}

Skenario dalam pengujian sensor adalah sensor dipasangkan pada ibu jari, jari telunjuk, dan jari tengah. Sensor diberi resistor dengan nilai $100 \mathrm{~K} \Omega$. Tegangan kerja sensor sebesar 5V. Masing-masing jari akan diluruskan selama 15 detik (5 kali looping), kemudian ditekuk penuh (dalam kondisi menggenggam) selama 15 detik (5 kali looping). Nilai yang dihasilkan dimasukkan ke dalam kode program pada Gambar 9. Adapun hasil pengujian sensor, berdasarkan skenario pengujian tersebut, dijabarkan pada Tabel 5. 
Tabel 5. Hasil Pengujian Sensor

\begin{tabular}{cccccc}
\hline No. & Sensor & $\begin{array}{c}\text { Kondisi } \\
\text { Jari }\end{array}$ & $\begin{array}{c}\mathrm{V} \\
\text { Sensor }\end{array}$ & $\begin{array}{c}\mathrm{R} \\
\text { Sensor }\end{array}$ & $\begin{array}{c}\text { Nilai } \\
\text { ADC }\end{array}$ \\
\hline \multirow{2}{*}{1} & Flex & Lurus & $5.02 \mathrm{~V}$ & $100 \mathrm{~K} \Omega$ & 429 \\
& $\begin{array}{c}\text { Sensor } \\
\text { Ibu Jari } \\
\text { Flex }\end{array}$ & Menekuk & $5.02 \mathrm{~V}$ & $100 \mathrm{~K} \Omega$ & 607 \\
& $\begin{array}{c}\text { Lensor } \\
\text { Jari } \\
\text { Telunjuk } \\
\text { Flex }\end{array}$ & Menekuk & $5.02 \mathrm{~V}$ & $100 \mathrm{~K} \Omega$ & 424 \\
& Lurus & $5.02 \mathrm{~V}$ & $100 \mathrm{~K} \Omega$ & 385 \\
& $\begin{array}{c}\text { Sensor } \\
\text { Jari }\end{array}$ & Menekuk & $5.02 \mathrm{~V}$ & $100 \mathrm{~K} \Omega$ & 591 \\
& & & & \\
\hline
\end{tabular}

Berdasarkan hasil pengujian pada Tabel 4 diperoleh informasi bahwa pada ibu jari didapatkan nilai paling kecil 429 pada saat ibu jari diluruskan, dan didapatkan nilai paling besar 607 pada saat ibu jari ditekuk. Sedangkan pada jari telunjuk diperoleh nilai $A D C$ minimal sebesar 424 ketika diluruskan, dan diperoleh nilai maksimal sebesar 684 ketika jari telunjuk ditekuk. Pada sensor jari tengah, diperoleh nilai minimal 385 pada saat jari diluruskan, dan diperoleh nilai maksimal pada saat jari ditekuk.

\section{Pengujian Delay}

Pengujian delay dilakukan untuk mengetahui selisih waktu pada saat paket hasil pembacaan sensor dikirimkan hingga nilai rotasi servo diterima oleh receiver. Skenario dari pengujian delay adalah modul transmitter dan receiver dihubungkan sebanyak 3 kali looping. Transmisi data menggunakan dua buah modul wireless nRF24L01 dengan jarak antar modul $40 \mathrm{~cm}$. Hasil pengujian delay dijelaskan pada Tabel 6.

Tabel 6. Hasil Pengujian Delay

\begin{tabular}{cccc}
\hline $\begin{array}{c}\text { No. } \\
\text { Iterasi }\end{array}$ & $\begin{array}{c}\text { Waktu Paket } \\
\text { Dikirim }\end{array}$ & $\begin{array}{c}\text { Waktu Paket } \\
\text { Diterima }\end{array}$ & $\begin{array}{c}\text { Selisih } \\
\text { Waktu } \\
\text { (millisecond) }\end{array}$ \\
\hline 1 & $09: 46: 55.357$ & $09: 46: 55: 617$ & 260 \\
& $09: 46: 55.391$ & $09: 46: 55.650$ & 259 \\
& $09: 46: 55.426$ & $09: 46: 55.685$ & 259 \\
2 & $09: 46: 55.960$ & $09: 46: 56.162$ & 202 \\
& $09: 46: 55.994$ & $09: 46: 56.195$ & 201 \\
3 & $09: 46: 56.020$ & $09: 46: 56.228$ & 208 \\
& $09: 46: 56.569$ & $09: 46: 56.702$ & 133 \\
& $09: 46: 56.603$ & $09: 46: 56.735$ & 132 \\
& $09: 46: 56.603$ & $09: 46: 56.769$ & 166 \\
\hline
\end{tabular}

Berdasarkan pengujian delay pada Tabel 6 diketahui bahwa selisih waktu berkisar antara 132 milisecond sampai 260 milisecond.

Berdasarkan klasifikasi delay pada Tabel 1 maka diketahui bahwa delay yang terjadi dalam pengujian pada Tabel 5 dikategorikan Bagus. Meskipun demikian, perlu diketahui bahwa motor servo yang digunakan dalam penelitian ini, memerlukan waktu sekitar 1-2 detik untuk melakukan rotasi dari $0^{\circ}-180^{\circ}$.

\section{Pengujian Fungsional}

Hasil pengujian fungsional merupakan hasil pengujian keseluruhan tangan prosthesis, terutama pada aspek fungsionalitas tangan prosthesis apabila digunakan sebagai alat bantu gerak. Hasil pengujian fungsional dijabarkan pada Tabel 7 .

Tabel 7. Hasil Pengujian Fungsional

\begin{tabular}{clc}
\hline \multirow{2}{*}{ No. } & \multicolumn{1}{c}{ Komponen Pengujian } & \multicolumn{2}{c}{ Keberhasilan } \\
\cline { 2 - 3 } & Berhasil & Tidak \\
\hline 1 & $\begin{array}{l}\text { Ibu jari dapat digerakkan } \\
\text { Jari telunjuk dapat } \\
\text { digerakkan }\end{array}$ & $\mathrm{V}$ \\
3 & $\begin{array}{l}\text { Jari tengah, jari manis, dan } \\
\text { kelingking dapat digerakkan } \\
4\end{array}$ & $\mathrm{~V}$ \\
5 & $\begin{array}{l}\text { Tangan dapat mengepal } \\
\text { Tangan dapat digunakan } \\
\text { untuk menggenggam benda } \\
\text { Tangan dapat digunakan } \\
\text { untuk mengambil benda }\end{array}$ & $\mathrm{V}$ \\
\hline
\end{tabular}

Berdasarkan pengujian fungsional yang dilakukan pada Tabel 7 dapat diketahui bahwa fungsionalitas tangan berjalan dengan baik, sebagaimana semua jari pada tangan berhasil digerakkan menirukan gerakan tangan pada transmitter. Selain itu, gerakan dasar tangan seperti menggenggam benda dan mengambil benda dapat dijalankan dengan baik. Diameter benda yang dapat digenggam terbatas pada panjang jari pada tangan. Salah satu dokumentasi pengujian fungsional ditunjukkan pada Gambar 10.

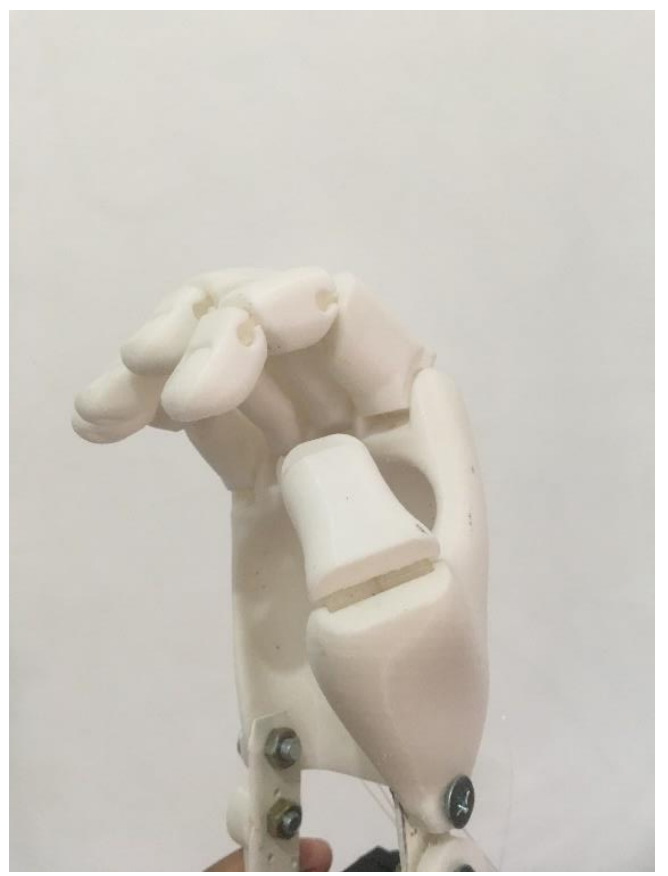

Gambar 10. Dokumentasi Tangan Prosthesis Pada Kondisi Mencengkeram 


\section{Kesimpulan}

Perancangan Tangan Prosthesis Bawah Siku Berbasis Flexy Hand 2 dan Flex Sensor telah berhasil dilakukan. Tangan prosthesis dibuat dengan base model Flexy Hand 2 yang dimodifikasi pada bagian lengan dan ditambahkan modul transmitter. Tangan prosthesis yang dibuat berhasil memperlebar ruang lingkup penggunaan Flexy Hand 2 yang semula hanya dapat digunakan oleh orang yang tidak mempunyai jari tangan, menjadi penyandang tuna daksa bagian bawah siku.

Tangan prosthesis yang dibuat dengan modul utama flex sensor ini dapat mengirimkan data ke modul receiver dalam rentang waktu sekitar 132 milisecond sampai dengan 260 milisecond. Tangan prosthesis bawah siku yang dibuat, dapat menjadi alat bantu gerak dengan gerakan dasar seperti menggenggam benda dan mengambil benda.

\section{Daftar Pustaka}

[1] Republik Indonesia, "Undang-Undang Negara Republik Indonesia No. 8 Tahun 2016 Tentang Penyandang Disabilitas," Sekretariat Negara, Jakarta, 2016.

[2] Republik Indonesia, "Undang-Undang Negara Republik Indonesia No. 4 Tahun 1997 Tentang Penyandang Cacat," Sekretariat Negara, Jakarta, 1997.

[3] Kementerian Kesehatan RI, "InfoDatin Pusat Data dan Informasi Kementerian Kesehatan RI : Penyandang Disabilitas Pada Anak," Pusat Data dan Informasi Kementerian Kesehatan RI, Jakarta, 2014.

[4] Kementerian Kesehatan RI, "BULETIN JENDELA : Situasi Penyandang Disabilitas," Pusat Data dan Informasi Sekretariat Jenderal Kementerian Kesehatan, Jakarta, 2014.

[5] Kementerian Kesehatan RI, "InfoDatin Pusat Data dan Informasi Kementerian Kesehatan RI : Diabetes," Pusat Data dan Informasi Kementerian Kesehatan RI, Jakarta, 2019.

[6] V. Vyawahare and D. Pardhi, "Design of Prosthetic Arm Using Flex Sensor," International Journal of Electronics and Communication Engineering and Technology (IJECET), pp. 1-6, 2017.
[7] Ottobock ID, "Panduan Pemula Tentang Tangan Palsu Prostetik," Ottobock, 2013. [Online]. Available:

https://www.ottobock.id/id/artikel/tanganpalsu/panduan-pemula-tentang-tangan-palsuprostetik/. [Accessed 30 October 2020].

[8] J. Owen, "ABOUT US - Enabling the Future," eNable, 2014. [Online]. Available: https://enablingthefuture.org/about/. [Accessed 30 October 2020].

[9] A. A. N. Amri and W. Sumbodo, "PERANCANGAN 3D PRINTER TIPE CORE XY BERBASIS FUSED DEPOSITION MODELING (FDM) MENGGUNAKAN SOFTWARE AUTODESK INVENTOR 2015," Jurnal Dinamika Vokasional Teknik Mesin, vol. 3, no. 2, pp. 110-115, 2018.

[10] Anon., "The Flexy Hand and Flexy Hand 2 Enabling the Future," e-Nable, 2016. [Online]. Available: https://enablingthefuture.org/upperlimb-prosthetics/the-flexy-hand/. [Accessed 30 October 2020].

[11] E. P. S. Oeoen, Jondry and U. N. Wisesty, "Klasifikasi Pergerakan Jari Tangan Berdasarkan Sinyal EMG Menggunakan Stacked Denoising Autoencoder untuk Mengendalikan Tangan Prostetik," e-Proceeding of Engineering, vol. 5, no. 3, pp. 7782-7789, 2018.

[12] A. Sreejan and Y. S. Narayan, "A Review on Applications of Flex Sensors," International Journal of Emerging Technology and Advanced Engineering, vol. 7, no. 7, pp. 97-100, 2017.

[13] U. J. Shobrina, R. Primananda and R. Maulana, "Analisis Kinerja Pengiriman Data Modul Transceiver NRF24101, Xbee dan Wifi ESP8266 Pada Wireless Sensor Network," Jurnal Pengembangan Teknologi Informasi dan Ilmu Komputer, vol. 2, no. 4, pp. 1510-1517, 2018.

[14] M. Rusdan, "Analisis Quality of Service (QoS) Pada Jaringan Wireless (Studi Kasus: Universitas Widyatama)," SISTEMIK, vol. 5, no. 4, 2017. 